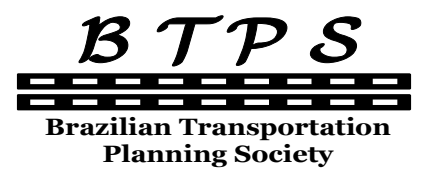

Planning Society

\author{
Journal of Transport Literature \\ Vol. 8, n. 4, pp. 316-328, Oct. 2014 \\ Research Directory
}

JTL | RELIT

www.journal-of-transport-literature.org ISSN 2238-1031

\title{
A complementary metric to define a buffer zone in Brazilian airports
}

[Uma métrica complementar para definir uma zona tampão em aeroporotos brasileiros]

\author{
Luiz André de Carvalho*, Jules Ghislain Slama, Carlos David Nassi
}

Federal University of Rio de Janeiro - Brazil

Submitted 6 Jul 2013; received in revised form 14 Apr 2014; accepted 8 Jun 2014

\begin{abstract}
The legislation on aircraft noise in Brazil recognizes the DNL metric as the only tool to perform noise airport zoning. This paper examines the importance of adopting an auxiliary metric to characterize the impacts of aircraft noise at a specific building sensitive to noise, especially in analysis of speech interference and sleep disturbance. A complementary measure, LAeq, associated with the Brazilian standard for controlling noise pollution, NBR 10151 (Assessment of noise in inhabited areas, for Community comfort), was used in this work. A control curve based the LAeq and on the standart was created and the buffer area between the control curve and DNL 65dB (A) was the object of study of this work. The results showed a high number of people who are affected by aircraft noise and are despised by the public authorities, only at Congonhas airport this number reaches the mark of 596,808 people. The adoption of complementary metric is intended to assist decision makers in identifying people highly annoyed by aircraft noise, allowing the creation of mitigation measures in the affected areas.
\end{abstract}

Key words: metric complementary, DNL, airport noise.

\section{Resumo}

A legislação sobre o ruído de aeronaves no Brasil reconhece a métrica DNL como a única ferramenta para implementar zoneamento de ruído em aeroportos. Este artigo analisa a importância da adoção de uma métrica auxiliar para caracterizar os impactos do ruído das aeronaves em construções específicas sensíveis ao ruído, especialmente na análise de interferência na fala e nos distúrbios do sono. Foi utilizado neste trabalho uma métrica complementar, LAeq, associada a norma brasileira de controle da poluição sonora, NBR 10151 (Avaliação do ruído em áreas habitadas para o conforto da Comunidade). Uma curva de controle baseada no LAeq e na norma foi criada e a área tampão entre a curva de controle e o DNL 65dB(A) foi o objeto de estudo deste trabalho. Os resultados mostraram um número elevado de pessoas que são atingidas pelo ruído aeronáutico e são desprezadas pelas autoridades públicas, só no aeroporto de Congonhas este número atinge a marca de 596.808 pessoas. A adoção da métrica complementar tem o intuito de auxiliar os tomadores de decisão na identificação das pessoas altamente incomodadas pelo ruído aeronáutico, permitindo a criação de medidas de mitigação nas áreas afetadas.

Palavras-Chave: métrica complementar, DNL, ruído aeroportuário.

*Email: ladca@yahoo.com.br.

\section{Recommended Citation}

Carvalho, L. A., Slama, J. G. and Nassi, C. D. (2014) A complementary metric to define a buffer zone in Brazilian airports. Journal of Transport Literature, vol. 8, n. 4, pp. 316-328.

- JTL/RELIT is a fully electronic, peer-reviewed, open access, international journal focused on emerging transport markets and published by BPTS - Brazilian Transport Planning Society. Website www.journal-of-transport-literature.org. ISSN 2238-1031. 


\section{Introduction}

This paper seeks to clarify the importance of using additional metrics, particularly those describing the noise impacts in places or situations sensitive to specific noises. The history of aircraft noise is intimately linked to the rise of aviation, however only from the 50s, with the emergence of large commercial jet aircraft and the increase the number of movements, this impact has been considered as critical. This rationale explains the reasons that motivated the National Civil Aviation Agency - ANAC - to propose the Brazilian Civil Aviation Regulation - standard RBAC 161, "Zoning Plan Noise - PZR".

The proposal RBAC161 replaces Ordinance No.1.141/GM5 of December 8, 1987, which describe Noise Zoning Plans - PZR which can be Basic (PBZR) or Specific (PEZR).

The PBZR is developed based on operational profiles standardized and it consists of simplified geometric curves to facilitate the implementation of the Plan to small aerodromes, with fewer aircraft movements and don't have the resources to prepare PEZR.

The PEZR is drawn using INM@ (Integrated Noise Model) software from specific operating profiles in order to better represent the physical and operational characteristics of each airport. It defines more precisely in the Zoning limits the land uses which are compatible and incompatible with aircraft noise levels, with consequent less harm to society.

The DNL metric, or "day and night noise level", was chosen for the preparation of PEZR noise curves for possessing several advantages, such as: being widely used for aircraft noise issues; correlated with Highly Annoyed People Percentage (Shultz, 1978); DNL based Airport Zoning Protection of the airport from encroachment.

However, one of the major problems of forecasting models DNL is that they tend to degrade in accuracy at great distances from airports. At the airport zoning, areas sensitive to noise are prohibited to level noise exceeding $65 \mathrm{~dB}(\mathrm{~A})$, but in practice, lower levels can cause annoyance too, it can't be considered as the only boundary between residential and non-residential areas (Slama, 2008). 
The DNL metric is not compatible with the sensitivity to noise that is observed at ground level (as is the NBR 10151) in the vicinity of airports, but with the noise of aviation. This detail is usually only realized after insertion of the curve DNL noise $65 \mathrm{~dB}(\mathrm{~A})$ at the airport, where experts note (and are surprised) that millions of people that living outside the proposed curve have some level of discomfort (usually high) in relation to airport noise.

Much of the criticism of the use of DNL to measure the nuisance of communities (U.S. EPA, 1978) and the compatibility of land use around airports stems from the inability to understand the basis for the measurement or calculation of this metric.

Metrics derived from the Brazilian standard NBR 10151 - the LaeqD (Day Equivalent Sound Level) and LAeqN (Night Equivalent Sound Level) provide a sound average for each period of the day, unlike the DNL, used in PEZR (specific plan zoning noise ) that calculates curves for a 24 hour period.

To obtain the auxiliary proposal curve to the DNL, were made correlations in the INM $\odot$ with standard NBR 10151, LaeqD and LAeqN, generating new values compatible with the standard that can be used by regulatory agencies and municipalities as a tool for the study of noise airport around airports.

It is expected that the results obtained may be useful in the planning of Brazilian airports, regarding nuisance that people feel in relation to aircraft noise. And they can also assist in expanding and modernizing them.

In the next topic will be addressed in more detail the relationship between complementary metric chosen and the NBR 10151. Then, the methodology of this study will be displayed, showing the calculations for obtaining the control curve and the respective LaeqD and LaeqN curves from airport to be studied. Soon after, a case study would be presented, defining: the choice of the airport studied; the definition of critical points; the localization of critical points within the proposed curve and analysis of results. Finally, the conclusion, interpreting the results and extolling the scientific contribution of this work. 


\section{Adoption of a Supplementary Metric X from NBR10151 Brazilian standard}

Some land uses sensitive to noise, referred in this article as critical points (schools, churches, hospitals and the like) are within or adjacent regions defined by the interior of the curves DNL noise $65 \mathrm{~dB}(\mathrm{~A})$, for an accurate analysis is helpful to adopt auxiliary metrics (additional) to determine the impacts of aircraft noise cause in these specific sites.

Slama et al. apud Revoredo (2011) mentions that besides the feeling of discomfort, the airport noise has many adverse effects of which the most important are: the interference in communication during the day and sleep disturbance during the night.

In Brazil, urban regulations for the control of noise pollution are based on the criteria shown in standard ABNT ${ }^{1}$ NBR 10151 for daytime and night-timeperiods, see Table 1 . The columns 2 and 3 represent the standard evaluation noise criteria levels for daytime and night time periods in each area.

Table 1 - Level Assessment Criteria (NCA) for outdoors, in dB(A)²

\begin{tabular}{lcc}
\hline Types areas & NCA & NCA \\
Diurnal & Nightly \\
\hline Areas of farms and ranches & 40 & 35 \\
Strictly residential area or hospitals or schools & 50 & 45 \\
Area mixed, predominantly residential & 55 & 50 \\
Mixed area, a commercial and administrative & 60 & 55 \\
Mixed area with recreational vocation & 65 & 60 \\
Predominantly industrial area & 70 & 65 \\
\hline
\end{tabular}

This paper will propose a new curve using a complementary metric, compatible with the Brazilian Standard NBR 10151 seen in Table 1. It is not intended to create a new zoning with this curve, but a simple alternative of monitoring of aircraft noise on the part of municipalities, since that they adopt that standard, and easy to understand for the general public.

It was decided in this study to use the complementary metric LAeq, divided into LAeqD (for the period Daytime) and LAeqN (for nighttime) as the instrument for obtaining this new

\footnotetext{
${ }^{1}$ Brazilian Association of Standart Techniques

2 \#Source: NBR ABNT 10151.
} 
proposed curve. It should be noted that this article will only concern the critical points (schools, hospitals, churches, etc.) and not residential areas, since the problem of encroachment in Brazil be considerable.

Dinato et al (2014) cited the LAeq and the SEL as complementary standards to the DNL to make the simulation of the acoustic noise in the vicinity of Ribeirão Preto airport but decided to apply the DNL in accordance with the regulations of RBAC161 of ANAC. Júnior et al (2012) used the SEL, the LAeq and the Lmax to measure the effect of aircraft noise on people around the Congonhas airport, not as a supplementary measure to the DNL. This paper, instead, the complementary curve will become an additional tool for decision makers in time to propose measures to mitigate noise around airports.

The encroachment or illegal occupation, besides generate environmental damage by dumping of solid and liquid waste, interferes with airport operations and with routines and operational aspects and safety (flight procedures), being a cause of constant surveillance (CAEP, 2003). This problem exists in most airports managed by Infraero $^{3}$, mainly in Congonhas airport, a major Brazilian airports.

\section{Methodology}

This study is divided into 4 parts. The first is the use of additional metrics chosen, the LAeq, to calculate the control curve proposed in this article. For the purpose of calculation the noise level at a critical receiver using LAeq, it is necessary to determine the period of time that is considered for the calculations. In this article was used the LaeqD (in order to consider the entire daytime period, from $7 \mathrm{am}$ to $22 \mathrm{pm}$ ) and LaeqN (in order to consider the night period, from $22 \mathrm{~h}$ to $7 \mathrm{am}$ the next day). The main purpose for the adoption of this metric is that it along with the DNL would assist local authorities in decisions about managing land use and zoning around the airport, due to its compatibility with urban Brasilian Legislation on Noise Pollution control.

\footnotetext{
${ }^{3}$ Airport Infrastructure Brazilian Company
} 
Considering the characteristics of noise and according to Table 1 was adopted in place of (daytime) NCA (Assessment Noise Criteria) the value of LAeqD and in place (night time) NCA the value of LAeqN.

The fundamental relationship between DNL, LAeqD and LAeqN for noise at a critical receptor located in the vicinity of an airport can be described according to the following equation:

$$
D N L=10 \log _{10}\left(\frac{1}{24}\left[15 \times 10^{\frac{L A e q D}{10}}+90 \times 10^{\frac{\text { LAeqN }}{10}}\right]\right)
$$

Whereby:

LAeqD = Equivalent sound level for daytime;

LAeqN = Equivalent sound level for the night time;

DNL = level day-night average sound.

Considering the Table 1 of standard ABNT NBR10151, from the values of LAeqD and LAeqN it is possible to determine the value of DNL for each area from equation 1, the results can be seen in Table 2 .

Table 2 - Results in DNL from equation1 of Table 1, dB(A)

\begin{tabular}{cccl}
\hline LAeqD & LAeqN & DNL & Tipos de áreas (NBR 10151) \\
\hline 40,0 & 35,0 & 42,6 & Areas of farms and ranches \\
50,0 & 45,0 & 52,6 & Strictly residential area or hospitals or schools \\
55,0 & 50,0 & 57,6 & Area mixed, predominantly residential \\
60,0 & 55,0 & 62,6 & Mixed area, a commercial and administrative \\
65,0 & 60,0 & 65,0 & Mixed area with recreational vocation \\
70,0 & 65,0 & 70,0 & Predominantly industrial area \\
\hline
\end{tabular}

It can be observed that the level DNL 52.6dB(A) in the NBR 10151 corresponds to the upper limit for the strictly urban residential areas or hospitals or schools. Having this curve DNL $52.6 \mathrm{~dB}(\mathrm{~A})$ as a limit of a control area, noise mitigation measures would be adopted. Another great advantage is that it would define a buffer zone between DNL 52.6dB(A) and DNL $65 \mathrm{~dB}(\mathrm{~A})$, where the critical receptors would be identified and monitored providing adequate acoustical treatments, without the need to create a new PZR. Below the DNL 52.6dB(A) there is no restrictions for the installation of noise sensitive activities. 
The airport chosen for the study is Congonhas International Airport, located in São Paulo which is Brazil's largest city, being historically considered the primary airport in the region. The main feature of this airport is its population concentrated unduly around. In Figure 1 it is possible to identify the three curves of the study.

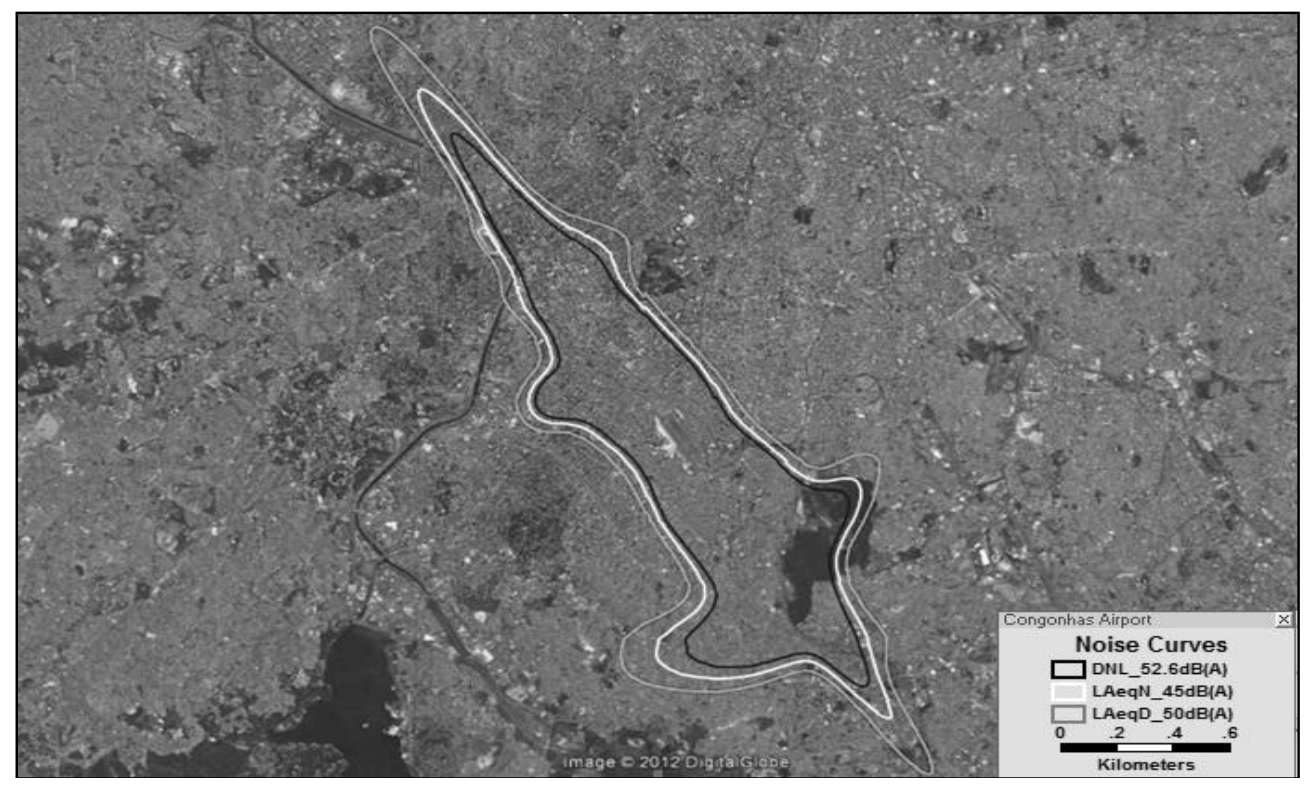

Figure 1 - DNL= 52.6dB(A), LAeqD=50dB(A) and LAeqN=45dB(A) on the Congonhas airport ${ }^{4}$

\subsection{Congonhas Airport}

In the second part, was chosen the airport being studied, the Congonhas Airport. Created in 1936, today has numerous restrictions of operations at various levels ranging from the operating hours limit until run up motors testing, completely invalidating its expansion.

Table 3 - Congonhas Airport ${ }^{5}$

\begin{tabular}{lc}
\hline Airport Site & $1.647 .000 \mathrm{~m}^{2}$ \\
Aircraft Site & $77.321 \mathrm{~m}^{2}$ \\
Runway Dimensions (1) & $1640 \times 45 \mathrm{~m}$ \\
Auxiliary Runway Dimensions (2) & $1345 \times 45 \mathrm{~m}$ \\
Passenger Capacity (2012) & 16.775 .785 \\
Passenger Terminal Area & $64.579 \mathrm{~m}^{2}$ \\
Aircraft Parking Positions & 29 positions \\
\hline
\end{tabular}

\footnotetext{
${ }^{4}$ \# Source: Study Group in Airport Noise - GERA (2013)

${ }^{5}$ \# Source: Infraero (2013)
} 


\subsection{Definition of Critical Points}

The third part of the study, sought to identify the critical points. The critical points mentioned were the "chosen" because they are considered noise sensitive buildings. For this paper were selected nine spots, as can be seen in Table 4, selected from educational and health institutions. For these points, noise levels at the metrics DNL, LAeqD and LAeqN, were calculated, with the help of software INM( ${ }^{6}$.

INM $\odot$ is used to evaluate the noise impact resulting from the expansion or construction of new runways to landing and takeoff, new traffic demands and composition of the fleet of aircraft, routes and revision of aerospace structures, alternative flight profiles and changes in other operating procedures (FAA, 1996).

The justification for adoption of INM@ is by its wide use in studies of noise from the airport activity and is widely recommended by the FAA.

\subsection{Insertion of Critical Points on the proposed Curve}

The fourth part of the study was to insert the critical points in the proposed curve. Selected points provide important information on how behave critical points and how curve DNL $65 \mathrm{~dB}(\mathrm{~A})$, defined by the $\mathrm{ANAC}^{7}$ and the FAA how limit for installation of critical points and residential, has no sufficient to characterize the noise situation in Brazil. Figure 2 below, illustrates the information that has been discussed above, it contains the following information: the smaller curve is the curve DNL $65 \mathrm{~dB}(\mathrm{~A})$ suggested by the Administrator and the FAA, the larger curve is the curve DNL $52.6 \mathrm{~dB}(\mathrm{~A})$, suggested by this article as a new reference for local governments and for aeronautics for the acoustic treatment of buildings at critical points and the black dots represent the respective critical points chosen for this study.

\footnotetext{
${ }^{6} \mathrm{INM} \odot$ is a computer model developed by the Federal Aviation Administration (FAA) that evaluates aircraft noise impacts in the vicinity of airports. It is based on an algorithm from the Society of Automotive Engineers e Aerospace Information Report 1845 standard (Procedure for the Calculation of Airplane Noise in the Vicinity of Airports).

${ }^{7}$ National Agency of Civil Aviation.
} 


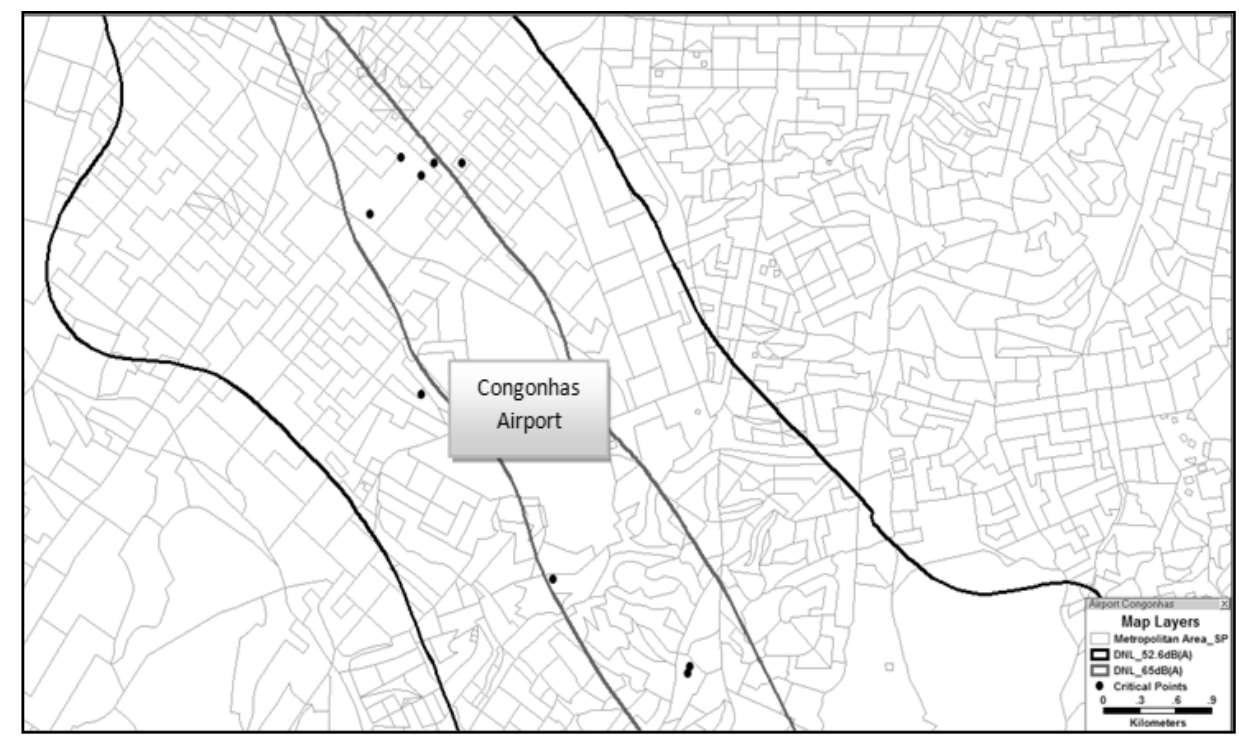

Figure 2 - Curves noise of 65 and $52.6 \mathrm{~dB}(\mathrm{~A})$ and critical points on the Congonhas airport ${ }^{8}$

The tool chosen for obtaining satellite information about land uses was Google Earth ${ }^{9}$, with satellite information it becomes possible to identify places, buildings, cities, landscapes, among other elements. In Table 4 it is possible to identify the nine critical points chosen, seen in Figure 2 , georeferenced by this tool.

Table 4 - Geographic coordinates of critical points chosen

\begin{tabular}{lcc}
\hline Critical Points & Latitude & Longitude \\
\hline College Paulicéia & -23.625051 & -46.665013 \\
College Maria Montessori & -23.608879 & -46.661807 \\
University Ibirapuera & -23.610175 & -46.664051 \\
College Augusto Laranja & -23.612482 & -46.66915 \\
College Linus Pauling Ed.Inf. & -23.637923 & -46.654451 \\
Hospital N.S. de Lourdes & -23.644006 & -46.643381 \\
CMI medical clinic & -23.64448 & -46.643608 \\
Hospital Centenário & -23.609795 & -46.665012 \\
HCI medical clinic & -23.608529 & -46.666718 \\
\hline
\end{tabular}

\footnotetext{
${ }^{8}$ \# Source: Study Group in Airport Noise - GERA (2013)

${ }^{9}$ Computer program developed and distributed by the American company Google. Google Earth@ displays a three dimensional model of the globe, constructed from mosaics of satellite images obtained from different sources, aerial images (photographed aircraft) and 3D GIS. The program can be used simply as a generator of twodimensional maps and satellite images or as a simulate or of these diverse landscapes on Earth. This makes it possible to identify places, buildings, cities, landscapes, among other elements.
} 


\section{Results}

\subsection{Analysis of results}

The results of Figure 2 show that the area in the interior of the curve DNL $65 \mathrm{~dB}(\mathrm{~A})$ does not adequately cover all the critical points. Proposal curve DNL $52.5 \mathrm{~dB}(\mathrm{~A})$, based on NBR 10151, thus becomes an excellent tool for decision makers because the area of your curve is greater and is covering all critical points selected, another big advantage is that it approaches the area where are located almost all complaints about aircraft noise. The residents of the city of Diadema, for example, located in the south of Congonhas Airport were not covered by the curve DNL $65 \mathrm{~dB}(\mathrm{~A})$, now with the curve DNL $52.6 \mathrm{~dB}(\mathrm{~A})$ which provides a more realistic situation, are covered in a extensive area of their municipality by curve proposal, as seen in Figure 3.

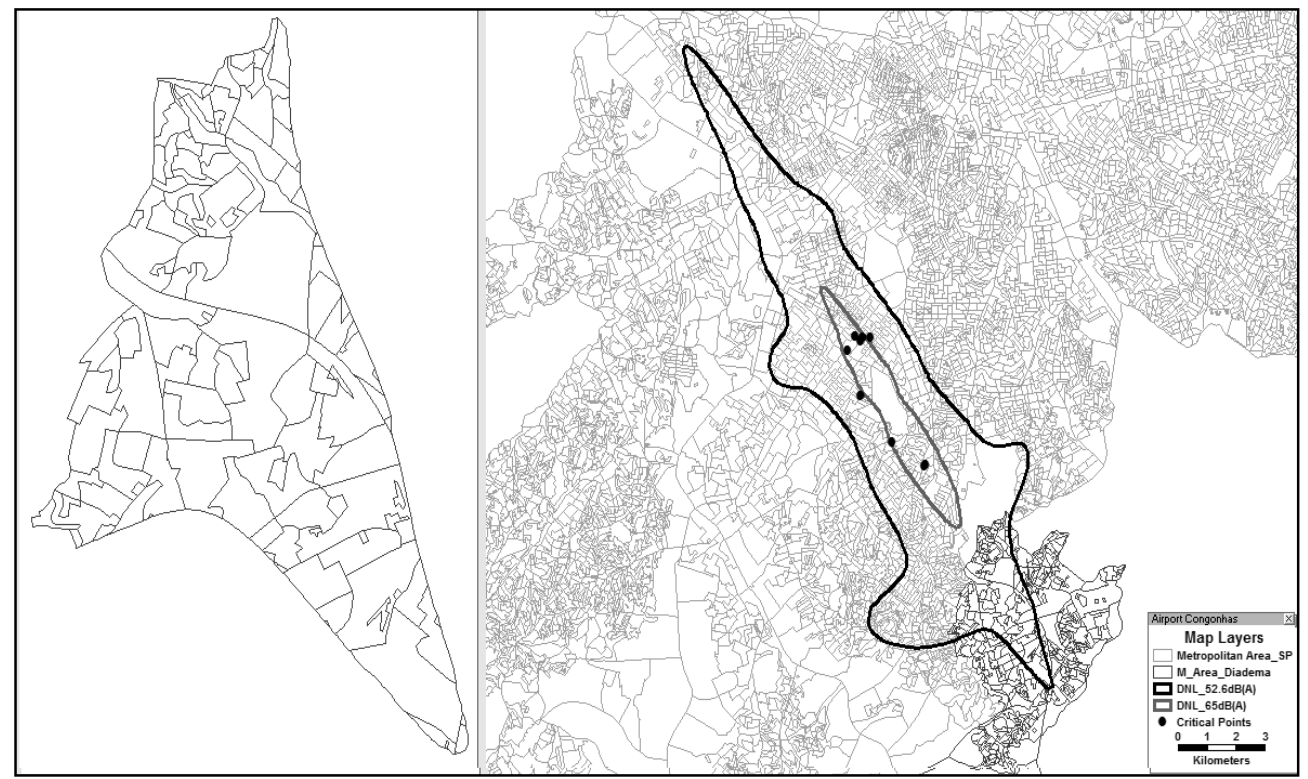

Figure 3 - Curves noise of 65 and $52.6 \mathrm{~dB}(\mathrm{~A})$ and critical points on the right Congonhas airport. City of Diadema inserted curve DNL 52.6dB(A) to the left ${ }^{10}$

It is Importantly to remember that article deals only with critical points mentioned above, but as is knowledge to all, the greater the population density in a region the greater be the amount of services it, and consequently of critical points. In Table 5 it is possible to identify what has

\footnotetext{
${ }^{10}$ \# Source: Study Group in Airport Noise - GERA (2013)
} 
been explained above, the results were obtained with the aid of INM( $)$ and of a tool SIG. $\left(\right.$ TransCAD@ $\left.{ }^{11}\right)$.

Table 5 - Relationship area versus estimated population in relation to the $\mathrm{DNL}$ values in $\mathrm{dB}(\mathrm{A})$

\begin{tabular}{cccc}
\hline \multicolumn{4}{c}{ Population within the risk area } \\
\hline City & DNL & Estimated Population & AreaCurve \\
\hline São Paulo & $65 \mathrm{~dB}(\mathrm{~A})$ & 54.732 & $7,55 \mathrm{~km}^{2}$ \\
São Paulo & $52,6 \mathrm{~dB}(\mathrm{~A})$ & 566.897 & $56,28 \mathrm{~km}^{2}$ \\
& $52,6 \mathrm{~dB}(\mathrm{~A}) \cap 65 \mathrm{~dB}(\mathrm{~A})$ & 512.165 & $48,73 \mathrm{~km}^{2}$ \\
Diadema & $52,6 \mathrm{~dB}(\mathrm{~A})$ & 84.643 & $7,89 \mathrm{~km}^{2}$ \\
\hline
\end{tabular}

At the intersection of In the region between the two curves it is possible to verify the existence of a significant amount of people suffering from the direct influence of airport in their lives and that they are ignored by the authorities, this number is nearly 10 times the number of people inside the curve DNL $65 \mathrm{~dB}(\mathrm{~A})$. It may also be noted that only the curve DNL $52.6 \mathrm{~dB}(\mathrm{~A})$ provides data for the city of Diadema, in which one can identify a considerable number of people in risk areas.

\section{Conclusions}

This paper showed the importance that an additional metric to the DNL presents in defining areas of risk. With the choice of LAeq, a metric compatible with NBR 10151, was possible to identify a considerable number of people within the area of risk between the control curve DNL $65 \mathrm{~dB}(\mathrm{~A})$ and curve proposed DNL $52.6 \mathrm{~dB}(\mathrm{~A})$. And where there are people, there are critical points (schools, hospitals, churches etc.), this article allows the responsible authorities identify and if necessary remove the critical points to areas outside of hazardous areas, adopting mitigation measures noise if necessary.

It is extremely positive the need for constant monitoring of aircraft noise around airports, including dissemination of results, so that they can forward solutions to the problems concerning the acoustic comfort of buildings. Also, assisting in the evaluation of chronic

\footnotetext{
${ }^{11}$ Transcad $\odot$ works in vector form, enabling the use of various layered files provided by the Brazilian Institute of Geography and Statistics (2013) and can befreely accessed.
} 
exposure in the elderly, children and adolescents, and their possible effects, such as: speech intelligibility, sleep interference and disorders in school activities.

It is observed that the constructive pattern of most critical points, in general, is the same used in other areas of the city that are not located in the flight path of aircraft from Congonhas airport, in other words, have no acoustic quality to soften the effect of aircraft noise.

According to ANAC the reference american DNL $65 \mathrm{~dB}(\mathrm{~A})$ was adopted by RBAC by reason of being successfully employed for longer and provide better conditions for suitability to the national urban context and be more compatible with the constructive characteristics of the buildings present in the Brazilian environment. The article cites the importance of adopting additional measures for critical points in Brazil, showing that the Brazilian reality differs U.S., mainly because ofencroachment.

The ANAC should propose policies to help the federal and state governments to establish policies and practices to minimize noise sensitive around airports, including areas outside of the curve DNL $65 \mathrm{~dB}(\mathrm{~A})$. The uses of additional metrics along with the DNL, provide benefits in relation to what is practiced today, such as: better describe the noise exposure for the general public can easily understand, facilitate a better public participation process to consider alternatives that lead to a consensus and allow authorities to select and implement a more effective noise reduction with mitigation measures.

This article proposes that only receive acoustic critical points inserted in the interior of the proposed curve, since there is no interest of the authorities to solve totally the problem of encroachment around airports.

\section{Acknowledgments}

We appreciate the collaboration of GERA (Airport Noise) Study Group/COPPE/UFRJ, and the support given by CNPq (Scientific and Technological Development National Council) and by CAPES (Coordination of Improvement of Higher Education Personnel). 


\section{References}

Associação Brasileira de Normas Técnicas - ABNT, NBR 10151. (2002) Avaliação do ruído em áreas habitadas, visando o conforto da comunidade - Procedimento. Associação Brasileira de Normas Técnicas, Rio de Janeiro, Brasil.

Agência Nacional de Aviação Civil - ANAC. (2011) Regulamento Brasileiro da Aviação Civil, RBAC $\mathrm{n}^{\circ}$ 161, EMENDA n ${ }^{\circ}$ 00. Planos de Zoneamento de Ruído de Aeródromos - PZR, Brasil.

Brasil. Portaria MAer. N. 1141/GM5 (1987) - Dispõe sobre zonas de proteção e aprova o Plano Básico de Zona de Proteção de Aeródromos, o Plano Básico de Zoneamento de Ruído, o Plano Básico de Proteção de Helipontos e o Plano de Proteção de Auxílios à Navegação Aérea e dá outras providências. Ministério do Estado da Aeronáutica.

Caliper (2007) TransCAD transportation GIS software: User's guide. Version 4.8. Massachusetts: Academic License, Newton.

CAEP. (2003) Methodology for Encroachment calculation: an application to Brazilian airports. Committee on Aviation Environmental Protection. Working Group 2: Airports and Operations. Bern, Switzerland.

Dinato, A. C., Schaal, R. E. (2014) Simulation of aircraft noise in the surroundings of the Ribeirão Preto airport. Journal of Transport Literature, vol. 8, n. 1, pp. 285-303.

Empresa Brasileira de Infraestrutura Aeroportuária - INFRAERO (2013) Normas e regulamentos. Rio de Janeiro: INFRAERO. Disponível em: 〈www.infraero.com.br >.

FAA. (1996) Integrated Noise Model, User's Guide versão 5.1. Federal Aviation Administration. Washington DC, USA.

FAA. (1985) Aviation Noise Effects. US Department of Transportation, Office of Environmental and Energy. Washington DC, USA.

Fernandes, J. C. (2002) Acústica e Ruídos. Apostila do curso básico de Pós-Graduação em engenharia mecânica da faculdade de engenharia da Unesp. Bauru, Brasil.

ICAO. (2004) Final draft of Guidance on the Balanced Approach to Aircraft Noise Management. Montreal, Canada.

Júnior, E. B. C., Garavelli, S. L., Maroja, A. M. (2012) Análise dos efeitos do ruído aeronáutico em zonas residenciais circunvizinhas ao Aeroporto Internacional de Brasília. Journal of Transport Literature, vol. 6, n. 4, pp. 59-81.

Nussenzveig, H. M. (2004) Curso de Física Básica. vol. 2. São Paulo, Brasil.

Schultz, T. J. (1978) Synthesis of social surveys on noise annoyance. Journal of the Acoustical Society of America, vol. 64, n. 2, pp. 377-405.

Slama, J. G., Mora-Camino, F. A. C. and Revoredo, T. C. (2008) Is DNL appropriate for airport noise zoning. In: European conference on Noise Control. Paris, French.

Revoredo, T. C. (2011) Estimação dinâmica do ruído aeronáutico utilizando sistemas diferencialmente planos e redes neurais artificiais. Tese (Doutorado em Engenharia Mecânica), Universidade Federal do Rio de Janeiro. Rio de Janeiro, Brasil.

U.S. EPA. (1978) Information on Levels of Environmental Noise Abatement and Control. Environmental Protection Agency Report 550/9-79-100. Washington DC, USA. 